\title{
THE TWO ASSES OF ZECHARIAH 9:9 \\ IN MATTHEW 21
}

\author{
David Instone-Brewer
}

\begin{abstract}
Summary
Matthew appears to depart from the Synoptics, Johannine tradition and from common sense when he gives Jesus two asses to ride on for his grand entrance into Jerusalem. Most commentators have assumed that Matthew misunderstood the meaning of the parallelism in Zechariah 9:9, which caused him to create another animal to enable Jesus to fulfil the prophecy. It will be suggested here that Matthew understood the concept of parallelism, but that he did not believe that Scripture should be interpreted in that way. This is in line with rabbinic thought of the first century which rejected the concept of parallelism in Scripture.
\end{abstract}

\section{Introduction}

All four Gospels record the entrance of Jesus into Jerusalem on an ass among the jubilant shouts of Hosanna. Although only Matthew and John explicitly link this with the prophecy of Zechariah, this prophecy is clearly implied in the version by Mark and Luke. Lindars suggested that Mark and Luke's accounts do not necessarily indicate any Messianic elements, so that the use of Zechariah is Matthew's idea. ${ }^{1}$ This seems unlikely. It is true that Hosanna can simply be an exclamation, and does not necessarily indicate the invocation 'Save now!'.2 It is also true that riding into Jerusalem in this way was not

1 Barnabas Lindars, New Testament Apologetic: The Doctrinal Significance of the Old Testament Quotations (London: SCM, 1961), 111-12.

2 Hosanna is either a clipped shorthand way of saying Hoshiah na, 'Save now', or it is an joyous exclamation of praise. Menahem Kister has argued strongly for the latter in 'Lexicographical Problems - Early and Late', in M. Bar-Asher, ed., Scripta Hierosolymitana XXXVII: Studies in Mishnaic Hebrew (Jerusalem: Magnes, 1998), 244-63, esp. 256-63. 
nearly as majestic as the recent entrance of Pilate, ${ }^{3}$ though it is impossible to escape the parallels with other triumphant arrivals. ${ }^{4}$ Lindars translates Mark 11:10 as 'Blessed is the coming kingdom of our father David' ${ }^{5}$ which could be used equally well of a messianic forerunner or prophet. Lindars argued that Jesus did not proclaim any messianic identity, and that this was a construct of the church, as illustrated by Matthew and John's development of this scene. ${ }^{6}$

Whether or not Mark and Luke regarded this entrance as Messianic, it is difficult to escape the conclusion that they would have associated it with the prophesy of Zechariah 9:9:

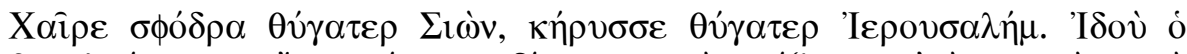

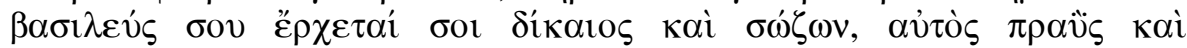

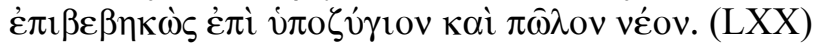

Rejoice greatly, $\mathrm{O}$ daughter of Zion; proclaim it aloud, $\mathrm{O}$ daughter of Jerusalem; behold the King is coming to you, just, and a Saviour; he is meek and riding on an ass, and a young foal. (LXX)

Many of the features of this prophecy can be seen fulfilled in the accounts of Mark and Luke. They even appear to emphasize elements of the story which fulfil the details in the text. Both Mark and Luke use $\pi \hat{\omega} \lambda \mathrm{o} \varsigma$ for 'colt' which is the more specific of the two terms used in the LXX. It is true that term could also refer to a horse, ${ }^{7}$ but Derrett points out that a horse would be too valuable to be left tied up in a public street. ${ }^{8}$ The elaborate descriptions of how the colt was tied and untied is perhaps a reference to the parallel Messianic prophecy in Genesis 49:10-11 about 'Shiloh' which also involves 'a foal, the colt of an ass' which is tied up. ${ }^{9}$ The detail that the colt had never been

3 See B. Kinman 'Jesus' "Triumphal Entry" in the Light of Pilate's', NTS 40 (1994) 442-48. He argues that the Roman soldiers ignored Jesus' entry because it was low key in comparison with Pilate's.

4 Dale Allison lists accounts in 1 Ki. 1:32-40, Zech. 9:9, 1 Macc. 5:45-54, 13:4 8, 13:49-53, 2 Macc. 4:21-2, Jos. Ant. 11.325-39, 13.304-306, 16.12-15, 17.193205, as well as others in Polybius and Suetonius in A Critical and Exegetical Commentary on the Gospel according to Saint Matthew (ICC 3 vols.; Edinburgh: T. \& T. Clark, 1988-1997), ad loc.

5 Along with C.K. Barrett, The Gospel according to St. John (2nd ed.; Philadelphia: Westminster, 1978), ad loc.

6 Lindars, NT Apologetic, 111-12. Similarly E.P. Sanders, Jesus and Judaism (London: SCM, 1985), 306-307.

7 W. Bauer, 'The "Colt" of Palm Sunday (Der Palmesel)', JBL 72 (1953) 220-29 says that $\pi \hat{\omega} \lambda \mathrm{o} \varsigma$ is 'horse' unless defined as an ass by the context, but see $\mathrm{O}$. Michel, TDNT 5.283-87.

8 J.D.M. Derrett, 'Law in the NT: The Palm Sunday Colt', NovT 13 (1971) 24158, esp. p 248.

9 This text was linked with messianic expectations in Zech. 9:9 from very early times. We see such speculations at Qumran 4QGenPesher (4Q252) col. V. 
ridden may also points to a king, because this heightened the dignity of the person riding it. ${ }^{10}$ However, this may also be an expansion of the LXX phrase 'young colt' ( $\pi \hat{\omega} \lambda$ ov véov). Derrett also showed that the request of 'The Master' for the ass was based on law of impressi which allowed a king to commandeer an animal to ride on, though admittedly this also applied to the servant of a king or to a respected scholar. ${ }^{11} \mathrm{He}$ says that the description of the king in Zechariah as 'poor' fits in with the fact that he commandeered the animal instead of hiring it. ${ }^{12}$ It is more likely that Mark and Luke followed the LXX and emphasised that the king was 'humble'. The cultural signigicance of an ass for first century Jews is difficult to assess because although asses were ridden by kings in the ancient Near East and the OT, 13 the horse was the normal vehicle for later kings, and the ass was a humble beast, or even a mark of derision. ${ }^{14}$

For the onlookers, one of the most significant details was the simple action of riding into Jerusalem. Jesus had walked till now, like most pilgrims, and just as he approached the city he sends for a mount. This is the reversal of what most pilgrims would do. If they could afford it, they would ride to Jerusalem, but for the final part of the journey they would walk. ${ }^{15}$ The fact that Jesus chose to ride into Jerusalem would make them ponder, and very quickly their minds

10 He backs this up by referring to m.San. 2.5 though this only speaks about the inappropriateness of a commoner riding a horse after a king has ridden it. Another reason which which is often suggested is a concern for religious cleanliness, as reflected in Num. 16:15, 1 Sam. 8:17 and in rabbinic concerns for uncontaminated seating. See Rudolf Stier, The Words of the Lord Jesus (Edinburgh, 1879) 3.90; O. Michel TDNT 5, 283-87 esp. 286; Derrett, 'Law in the NT', 249.

11 Derrett, 'Law in the NT', 241-58.

12 He points out that it was safer to hire an animal if one could afford it because Ex. 22:14-15 said that a borrower had to pay damages if the animal was harmed. (Derrett, 'Law in the NT', 250).

13 The ass is a royal animal in $1 \mathrm{Ki}$. 1:33, 38, also 2 Sam. 18:9, 19:26, cf. Jud. 5:10, 10:4, 12:13-14, 2 Sam. 13:29 and riding a mule for a ceremonial entrance to a city was a very ancient practice, found already in ANE Mari texts (ARM 6.76) and Sumerian 'Gilgamesh and Agga' where those who 'are raised with the sons of the kings' are called those who ride donkeys (ANET 1 44-47).

14 Lieuviarts, L'entrée de Jesus à Jérusalem, 74, refers to the well-known 2nd century anti-Christian graffiti of someone worshipping as ass-headed crucified figure ('Alexamenos worships his god' - for illustrations and discussion see http://faculty.bbc.edu/RDecker/alex_graffito.htm).

15 See the House debate at m.Hag.1.1 where both the Hillelites and Shammaites assume that a pilgrim must walk into the city. The Hillelites base this on a wordplay with 'times' (רגל ים) in Ex. 23:14 'three times you must appear', which they read as 'feet' (from רגר). For a fuller analysis see my Techniques and Assumptions in Jewish Exegesis before 70 CE, (Texte und Studien zum antiken Judentum, 30; Tübingen: Mohr, 1992), 140-41. 
would be drawn to Zechariah 9:9. As an early treatise on dream interpretation pointed out, an ass should always make one think of the messiah because of the association with Zechariah 9:9.16

It is inconceivable that any Christian readers of Mark or Luke could have missed their allusions to the prophecy in Zechariah 9:9. The end of Zechariah contains many of the church Testimony texts identified by Dodd, ${ }^{17}$ and (as seen below) it was widely used in Jewish circles. Matthew felt it necessary to cite the text, probably because this marked the beginning of a series of citations of Zechariah which Lindars called the 'Zechariah Passion commentary'. ${ }^{18}$ This leaves us with the question of why Matthew felt it was necessary to record an extra ass. As Hagner said: 'It is almost impossible to argue that Matthew believed two animals were necessary, rather than the single animal of Mark for the prophecy of Zechariah to be regarded as fulfilled.' 19 Hagner said this in the belief that Matthew would have accepted parallelism as a valid way to interpret Scripture. I will now show that, although non-rabbinic Judaism and also later rabbinic authorities accepted parallelism in Scripture, the rabbinic Judaism of the first century assumed that Scripture contained no parallelism.

Zechariah 9:9 was the subject of much discussion in later rabbinic literature..$^{20}$ It does not appear in any form which can be definitely dated before $70 \mathrm{CE}$, though the dream interpretation text which is mentioned above made Klausner conclude that messianic interpretations of Genesis 49:11 and Zechariah 9:9 date at least from the Tannaitic period. ${ }^{21}$ The absence of early exegeses of these texts in rabbinic literature is not surprising. Virtually all the early rabbinic material is halakhic and only about one hundred exegeses from before

16 b.Ber $56 \mathrm{~b}-57 \mathrm{a}=$ b.San.99a; Midrash Rabbah Gen.75.6 contains a Tanaitic discussion (i.e. 1st to mid 3rd century CE) about symbolism in dreams. It lists the symbolic value of various animals, including an ass: "An ass refers to the royal Messiah, for it says of him, "Lowly, and riding upon an ass" (Zech. IX, 9)' and 'and if one saw a choice vine let him expect the Messiah, as it is written, (Gen. 49:11) "Binding his foal to the vine and his asses colt to a choice vine".

17 C.H. Dodd, According to the Scriptures: The Substructure of New Testament Theology (London: Nisbet, 1952), 107.

18 Lindars NT Apologetic, 111-12. Zech. 12:10-14 in Mt. 24:30; Zech. 14:5 in Mt. 25:31 (a possible allusion), Zech. 11:12 in Mt. 26:15; Zech. 13:7 in Mt. 26:31; Zech. 11:13 in Mt. 27:3-10.

19 D.A. Hagner, Matthew 14-28 (WBC 33b; Dallas: Word Books, 1995) ad loc.

20 Amoraic discussions of the Zech. 9:9 are found in b.San.98a, 99a; Midr. Rab. Gen.98.9, 99.8, Ex. 30:4, Deut. 4:11, Cant. 1:29, Eccl. 1:28; All the discussions assume that the text is messianic and none of them refer to more than one ass.

21 Joseph Klausner, The Messianic Idea in Israel: from Its Beginning to the Completion of the Mishnah (London: Allen and Unwin, 1956), 439. 
70 CE have survived. ${ }^{22}$ Also, messianic discussions were discouraged by the early rabbis, so one often has to look for clues in the LXX or Qumran to discover the type of discussions which were likely to have been occurring in rabbinic circles without being recorded. Qumran discoveries have not unearthed any commentary on Zechariah 9:9, but the Genesis Pesher 4Q252 col. V does discuss the beginning of Genesis 49:10-11 in a very similar vein to later rabbinic messianic interpretations, ${ }^{23}$ though the fragment ends before it discusses the asses. The LXX translation of Zechariah 9:9 is very literal, and the only real deviance from the MT is the ambiguous translation of the

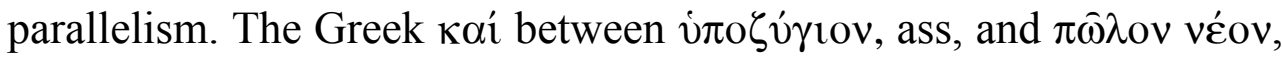
young colt, could indicate either an equivalence, as one might expect when translating parallelism, or it may indicate that there were two separate animals.

Many commentators have discussed whether Matthew was following the LXX without knowing the Hebrew, or whether he was deliberately using the ambiguity of the LXX to bring out nuances of the text. Some have even accused him of being completely ignorant about the concept of parallelism. ${ }^{24}$ Others have pointed out that he must have been familiar with the Hebrew text because his translation is closer to the MT than the LXX. This is especially with regard to his translation of the first term for an ass with the specific term ovvo $\varsigma$

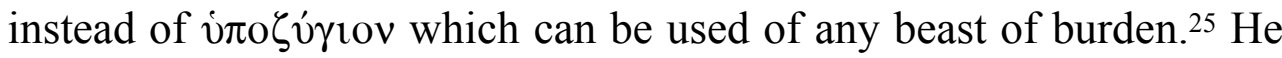
slavishly followed the Hebrew by putting é $\pi \dot{i}$ in front of both animals, which heightens the idea that the king rides on both of them. ${ }^{26} \mathrm{He}$ also omits the phrase 'righteous and having salvation', perhaps because he realized that the Hebrew should more properly be translated as 'righteous and being saved'. ${ }^{27} \mathrm{He}$ agrees with the LXX against the

22 See my Techniques and Assumptions which collects them all.

23 See especially Midrash Rabbah Gen.99.8

24 David R. Bauer, Treasures New and Old: Recent Contributions to Matthean Studies (SBL Symposium Series 1; Atlanta: Scholars, 1996), 35 replies to the claim in John P. Meier, The Vision of Matthew: Christ, Church, and Morality in the First Gospel (Theological inquiries; New York: Paulist, 1979), 19-21 that Matthew's misunderstanding of parallelism may suggest that he was a Gentile.

25 See Hagner, Matthew, ad loc. and J.J. Menken, 'The Quotations from Zech 9, 9 in Mt 21, 5 and in Jn 12, 15' in A. Denaux, ed, John and the Synoptics (BETL CI; Leuven: Leuven University Press, 1992), 571-78 esp. 573.

26 Menken 'Quotations', 573-74 notes that it occurs in Symmachus, Theodotion and Quinta, and argues that it may have been a reading of Aquila.

27 See R.C.H. Lenski, Interpretation of St Matthew's Gospel (Columbus, Ohio, 1932), ad loc. This does not bother the later rabbinic commentator at Midrash Rabbah Ex. 30:24: 'It does not say moshia' (a saviour), but nosha' (was saved), thus implying that even if you have no good deeds to your credit, God will bring 
MT only when he translates 'ענ, 'meek' as if it read ענו, 'humble'. However, as Gundry points out, the Targums, Peshitta and Aquila all agree with Matthew, so perhaps there was a Hebrew tradition which contained this reading. 28

It is very unlikely that a well-read Jew would misunderstand parallelism. This type of poetic construction was still being used as late as Baruch and 4 Esdras. ${ }^{29}$ However, as I have shown elsewhere, the rabbinic authorities before $70 \mathrm{CE}$ totally rejected the concept of synonymous parallelism in Scripture. ${ }^{30}$ They regarded Scripture, including the Writings, as a perfect law. One of the characteristics which they assumed to be part of a perfect law was the lack of redundancy. Any unnecessary repetition involved redundancy, and implied sloppy writing by the divine legislator. This did not mean that they only rejected parallelism which was exactly synonymous, if this ever exits ${ }^{31}$. They also rejected parallelism which adds details which were not present in the first line. They do so because a perfect legislator would have used one line or the other - either a general phrase which would imply the more specific or a specific phrase which would be an example of the general.

salvation for His own sake.' Many others have suggested that it is because this omission puts more emphasis on the word 'humble' — see e.g. Günther Bornkamm et al., Tradition and interpretation in Matthew (NTL; London: SCM Press, 1963), 129f; R.H. Gundry, The Use of the Old Testament in St. Matthew's Gospel, with Special Reference to the Messianic Hope (NovTSup 18; Leiden: Brill, 1967), 120.

28 R.H. Gundry, Matthew: A Commentary on His Literary and Theological Art (Grand Rapids: Eerdmans, 1982), ad loc.

29 See George Buchanan Gray, The Forms of Hebrew Poetry: Considered with Special Reference to the Criticism and Interpretation of the Old Testament (The Library of Biblical studies; [New York]: Ktav, 1972), 10-31. He points out that the first Jews to clearly describe parallelism are Kimchi, (1160-1235) and Ibn Ezra (1093-1168). However there is much evidence that parallelism was understood by first century Jews. He analyses the parallelism which is found in Baruch 48:1-47, 4 Esdras 8:20-30, as well as pointing to many other texts such as the Damascus Document, the Odes of Solomon, the Eighteen Benedictions, the earliest blessings accompanying the Shema, Testimonies of the Twelve Patriarchs and Jubilees. Josephus and Philo do not mention parallelism when they discuss Hebrew poetry because they are keen to show that it is like Greek poetry, but this does not mean that they did not know or recognise parallelism.

30 See my Techniques and Assumptions, 166-67 Krister Stendahl, The School of St. Matthew and Its Use of the Old Testament (Acta Seminarii Neotestamentici Upsaliensis, 20. 2nd ed.; Lund: Gleerup, [1968]) 119, implied that rabbinic exegesis did not accept parallelism, but he gave no examples to demonstrate this.

31 Alter and Kugel argue that the second line always contributes something which is not present in the first line, so no parallelism is truly synonymous. Alter says that the second line usually adds specificity or intensification. See Robert Alter, The Art of Biblical Poetry (New York: Basic Books, 1985), 18-22. 
One pair of early debates from the first century BCE illustrates this very well. In these debates Bar Hé Hé complains about two apparent examples of synonymous parallelism in Scripture. Hillel manages to find a reason for the independent necessity of both halves of each text. Even though Bar Hé Hé believes the two halves are different, Hillel's explanation for the second text is not always immediately acceptable to him. To a modern reader, both of Hillel's explanations appear forced. This shows how important it was for the early rabbis to explain away all appearances of parallelism in Scripture. Presumably these two explanations represent a huge number of similar ones concerning other texts which have not survived.

m.Hag.1.6, b.Hag.9b:

Mishnah: [If] the festival passes and no offering [has been made] he is not liable for the debt. Of this one it is said: 'The crooked cannot be straightened and that which is lacking cannot be counted' [Qoh. 1:15].

Gemarah: Bar Hé Hé said to Hillel: This 'be counted' ought to be 'be filled.

[Hillel said] But this [refers to] he whose associates counted him in for a religious act but he would not [let himself] be counted with them.

Bar Hé Hé [said] to Hillel: what [means] the text: 'And you will return and distinguish between the righteous and the wicked, between him who serves God and him who serves him not.' [Mal. 3:18]. The 'righteous' is the same as 'he who serves God' [and] the 'wicked' is the same as 'he who serves him not'.

[Hillel] said to him: 'He who serves' and 'he who serves not' are both those who are perfectly righteous. But one should not compare him who repeats his chapter a hundred times with him who repeats his chapter a hundred and one times.

[Bar Hé Hé ] said to him: And because of a single time he is call 'he who serves him not'? [Hillel] said to him: Yes. Go and learn from the market of the ass drivers. Ten portions for a single zuz. Eleven portions for two zuz.

The first text which concerns Bar Hé Hé is one which has a traditional interpretation, as preserved in m.Hag.1.6. This suggests that synonymous parallelism in Scripture was acceptable to some predecessors of Hillel. Bar Hé Hé first points out that the parallelism is not truly synonymous, because it were, the second phrase should have been 'that which is lacking cannot be filled'. He is not proposing an emendation. The type of interpretation which relied on a mental emendation of the text was later called al tiqre and became popular after $70 \mathrm{CE}$. He was concerned only to point out that there was something wrong with this traditional exegesis. Hillel (or perhaps Bar Hé Hé himself - the text is not clear) proposed a solution. The second half of the text concerns someone who was 'counted in' by his fellows when they were offering a required sacrifice. He had not yet arrived at the festival, so his fellows put his name forward as one of 
the people responsible for the offering when they brought it. However, when this person arrived, he decided that he didn't want to be 'counted in' with this sacrifice, and repudiated his part in the offering. Bar Hé Hé must have been very keen to remove the synonymous parallelism if he was willing to accept that it was addressing such an unlikely occurrence.

The second text is an even clearer example of synonymous parallelism, but Hillel manages to make a distinction between the two lines. It is not sufficient for him to show that the second line says something slightly different to the first. He could have said that the second line defines the meaning of 'righteousness' and 'wickedness' in terms of service to God. Although this would provide a reason for the line's existence in literary terms, it would not provide a reason for its existence in legislative terms. In literary terms the second line was not redundant because it helped to explain the meaning of the first line. But in legislative terms, the second line was simply restating the same matter in different words. One way to understand Hillel's concerns is that he, like other rabbinic authorities before $70 \mathrm{CE}$, regarded the whole of Scripture in terms of a legal document, and this underlay their whole approach to its interpretation. ${ }^{32}$

Hillel proposed that those who 'serve' God or not, are those who are diligent or not in their lessons. Even a single failure to repeat a lesson can cause one to be counted among those who do not serve God. Hillel would have said that both groups of students will have eternal life, because God would have mercy on those who had not served him completely. ${ }^{33}$

These fascinating texts tell us a great deal about the way in which the early rabbinic authorities thought about Scripture, and in particular the way in which they completely rejected any concept of synonymous parallelism, even in the Writings and the Prophets. If Scripture was written by the divine legislator, each line must carry equal weight, and represent a new truth or a new law. This was probably only true of the rabbinic authorities within Palestine. The principles of interpretation which flow from this understanding of Scripture are found only in the rabbinic literature which can be dated

32 See my Techniques and Assumptions, 163-71.

33 This assumes that the Hillelites followed their master in this matter. See t.Sanh.13:3 (b.RH.16b-17a; ARNa.41): Beth Shammai say: [There are] three classes, one for eternal life, one for shame and eternal abomination (these are completely evil) and the evenly balanced who go down to Gehenna and squeal and rise again and are healed. ... And Beth Hillel say: [He who has] great mercy inclines towards mercy. 
before $70 \mathrm{CE}$. After this period, and outside the confines of this group of interpreters, in Qumran and Alexandria, we find a completely different approach to Scripture ${ }^{34}$ and in later rabbinic expositions of this text there is no reference to two animals.

In the light of this it is clear that these early rabbinic authorities would not regard Zechariah's text to be fulfilled by Jesus if he simply rode into Jerusalem on a young ass. For this reason Matthew feels it is necessary that Jesus rode on two asses. John is happy to combine the parallel lines into one phrase 'Behold, your king is coming, sitting on an ass's colt' (Jn. 12:15), but Matthew keeps the two halves separate: 'Behold, your king is coming to you humble, and mounted on an ass, and on a colt, the foal of an ass.' John represents the majority of Judaism at the time, which was happy to accept parallelism as a feature of poetry in Scripture and in other literature. Matthew, however, represents the rabbinic authorities who were not yet ready to read Scripture like any other literature - a revolution which would have to wait till R.Ishmael and R.Aquiva. ${ }^{35}$

We find a similar situation with the fulfilment texts of the Passion narratives. Mark alludes to the two halves of Psalm 69:21 — the first half ('They gave me also gall for my food') when they offer Jesus gall on the way to the cross (Mk. 15:23) and the second half ('And in my thirst they gave me vinegar to drink') when a soldier offered him vinegar on the cross (Mk. 15:36). John and Luke are happy to omit the first reference and only mention the vinegar (Lk. 23:36; Jn. 19:2829), but Matthew keeps both halves (Mt. 27:34, 48). For Matthew it was important to show that both halves had a separate fulfilment.

We are left with the question of historicity. Did Matthew invent the second ass in order to fulfil Scripture, ${ }^{36}$ or did he have access to a tradition which the others did not know or did not see any reason to

\footnotetext{
34 See my Techniques and Assumptions 215-21.

35 R.Ishmael was attributed with the saying that "Scripture speaks with the language of men" (b.Ber.31b; b.Ned.3a) and with a new set of rules for interpretation. It is likely that some of these rules originated with Aquiva whose exegeses illustrates this revolution far better than those of Ishmael. Both men thrived in the mid second century. Gray says that even in the second century the rabbis often interpreted the first of two parallel lines with regard to this life, and the second with regard to eternal life (Gray, Forms of Hebrew Poetry, 20 referring especially to the collection of exegeses in m.Sanh.10.3). Gray gives this as an example of rabbis recognising parallelism in Scripture, but actually it is an example of them rejecting it, because they interpret the synonymous lines as though they meant different things.

36 Gundry, Use of OT in Matthew, 197: 'Zech 9:9 in Mt 21:5 is most universally considered an instance of prophecy creating tradition.'
} 
include? As Straus said in his famously sarcastic way, it seems unnecessarily cumbersome to introduce a second animal and have Jesus ride both animals. ${ }^{37}$ The only result of this would be to open up Matthew's account to ridicule. For this reason, he assumes that Matthew had access to a tradition and that he recognized this kind of detail would enthral a certain type of reader. Early commentators felt that the solution must be allegorical. The older ass is the Jews who have been used to the yoke of the Law, while the younger untied and unmounted ass is the Gentiles. ${ }^{38}$ Or perhaps Matthew was developing a typology of Moses or David. ${ }^{39}$ Some have seen his act as a necessity or a kindness given the fact that the colt was not ready to be separated from its mother ${ }^{40}$ Others have said that Matthew simply invented the second ass, in the same way that he invented a second blind man and a second demoniac, ${ }^{41}$ perhaps a result of his pedantry, ${ }^{42}$ and he has made an ass of himself as a result.

I feel that the actual process of Matthew's mind lies somewhere inbetween. Although it is possible that Matthew had independent knowledge of a tradition about a second ass, this seems unlikely. This does not mean, however that Matthew would have felt able to invent the second animal. In Matthew's mind it was obvious that Jesus' action was fulfilling the prophecy of Zechariah, but it was equally obvious that the prophecy spoke about two animals. He would have felt able to

37 David Friedrich Strauss, The Life of Jesus Critically Examined, Lives of Jesus (London: SCM, 1973), 553.

38 See the collection of comments in Harold Smith, Ante-Nicene Exegesis of the Gospels, Translations of Christian Literature, Series 6 (London: SPCK, 19251929), ad loc. for quotations from Origen Matthew 1614 p. 737 and Homily 13.8 and Justin Martyr Dialogue 53.

39 Allison, ICC Matthew ad loc suggests it may be a typology based on Moses whose family travelled on two asses - LXX Ex. 4:19-20 'Moses travelled with asses'. See also Lieuviarts (L'entrée de Jésus à Jérusalem, pp. 72-73) who points to Pirke R Eliezer cited by rashi re Ex. 4:20 — Moses and his family returned on asses to Egypt, and to Matthews use of 'out of Egypt' as part of a Moses typology. But there is only one ass in the similar reference to Moses in Midrash Rabbah Eccl.1.28. Menken, 'The Quotations from Zech 9, 9 in Mt 21, 5 and in Jn 12, 15' in A Denaux, ed, John and the Synoptics, 571-78 esp 574 suggests the 2nd ass is from 2 Sam. 16:1-4 where David flees on a couple of donkeys (i links it to the phrase 'son of David' in this pericope.

40 Spurgeon, Gospel of the Kingdom, ad loc. says that this shows how gentle Jesus was.

41 For example, two blind men at 21.1-9 instead of one Bartimaeus and two demoniacs at 8:28-34 instead of one called Legion in Mk.

42 Bellinzoni says that Matthew is as pedantic here as he is at 14:21, where Mark has 'men' and Matthew writes 'not including women and children'; Arthur J. Bellinzoni, Jr., The Two-source Hypothesis: A Critical Appraisal (Macon, Ga: Mercer University Press, 1985), 71 n. 19. 
extend the account of Jesus' entrance by using the information he found in Zechariah. This was Scripture, after all, and therefore it was correct in every detail. Zechariah's witness was more weighty than that of Mark, so if Zechariah said there were two animals, it was safe for Matthew to record the fact. It is interesting that Justin Martyr reasoned exactly the same way when he concluded that the ass had been tied to a vine, based on Genesis 49:10-11.43 Given the fact that there was an older and a younger ass, and based on Mark's description of the younger as unridden, it is then a relatively logical step to conclude that the young ass was accompanied by its mother. The first 'ass' in the MT is male, but this would not preclude a female being meant, because there was no neuter equivalent. ${ }^{44}$ The other Gospel which Matthew was using suggested that the animal had not yet been weaned, so it was likely that it would still be accompanied by its mother - a scene which can still be seen in Palestine. ${ }^{45}$

This still leaves the matter of the 'circus trick' 46 where Jesus rides two animals. This has exercised commentators and copyists from the earliest times. Commentators have often argued that the ambiguous 'them' which Jesus sat on refers to the garments. ${ }^{47}$ However, it is difficult to get away from the conclusion that Matthew wanted to include both animals in every aspect of the event, including the act of being ridden.

Mk.11:2 'you will find a colt tied'

Mt.21:2 'you will find an ass tied and a colt with her'

Mk.11:3 'untie it and bring it.... the Lord has need of it'

Mt.21:3 'untie them and bring them... the Lord has need of them'

43 Apol. I 32. See also an undatable saying in b.Ber.57a.

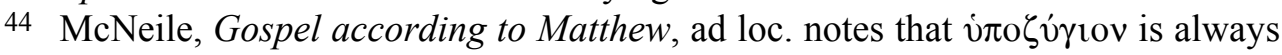
a he-ass in LXX except in Jud. 5:10, cf 2 Pet. 2:16.

45 R. Winterbothom, 'The Ass and the Ass's Colt: St. Matthew xxi. 1-7' ExpTim 28 (1916-17) 380-81 went to ask a farmer who said that a colt could not be persuaded to go without the mother in this type of situation. Gundry, Matthew... Theological Art, re 21:2 says that 'The sight of an unridden donkey colt accompanying its mother has remained common in Palestine up to modern times', though in Matthew it is the colt which is ridden. It was normal for a colt to always remain with its mothers, even if the mother was sold - see m.BB.5.3: 'He who sells an ass has sold the foal'.

46 McCasland charges Matthew with 'changing Mark's simple, dignified narrative of this historic event into something like a circus spectacle', due to 'Matthew's failure to understand the poetic lines' (S.V. McCasland, 'Mt Twists the Scripture', $J B L 80$ (1961) 143-48, pp. 144-45.

47 Chapman, Matthew Mark and Luke, 266 lists Theophylact, Euthymius 'and some moderns'. 
Mk.11:8 'they threw their garments on it and he sat on it'

Mt.21:8 'they threw their garments on them and he sat on them'

Medieval illustrators have portrayed Jesus astride the mother, with the colt walking underneath her so that Jesus' legs are astride the colt as well. Otto Michel has said that Matthew envisioned an oriental chair which was often strung across two animals ${ }^{48}$, though I doubt that anyone would chose two animals of different sizes. Others have suggested that Jesus changed animals periodically in order to give the young colt a rest, though Strauss points out that this would have been inconvenient during such a short journey ${ }^{49}$.

Again, we have to look at the matter through the eyes of Matthew, the first century Jewish exegete. Matthew did not restrict himself to exegetical techniques which were used by first century rabbinic authorities, but their habit of exegeting both halves of a parallelism probably appealed to his penchant for interpreting small details in the OT text.

Having decided that Zechariah's prophecy involves two animals, and having concluded that they were a mother and her young colt, it was logical that the mother would accompany her colt in the journey. Matthew regarded both animals as integral to the fulfilment of the prophecy, and wanted to include them both in every aspect of the event. This applied especially to the matter of being ridden, because this was specifically mentioned in Zechariah. I do not think that he meant us to picture Jesus astride both animals. He simply wanted to show that both animals were fully involved in the process of conveying Jesus to the city. Matthew's phrase 'he sat on them' is ambiguous, referring either to the asses or the garments, and perhaps this is deliberate. He did not wish to conclude exactly how the prophecy was fulfilled. He was happy merely to indicate that everything was done, as Scripture indicated in Zechariah 9:9. Matthew's motive is not so much to prove from his account that Scripture has been fulfilled. This had already been accomplished by Mark's account. Matthew wished to use Scripture to fill out his account of Jesus' entry into Jerusalem using the details which he found in Zechariah 9:9.

$48 \quad T W N T 6.961$.

49 Strauss, Life of Jesus, 553. 